\title{
Skill Development In Social Science Subjects: A Proposed Methodology
}

Juan-Antonio Mondéjar-Jiménez, Ph.D., University of Castilla-La Mancha, Spain

María Cordente-Rodríguez, University of Castilla-La Mancha, Spain

Carlota Lorenzo-Romero, Ph.D., University of Castilla-La Mancha, Spain

José Mondéjar-Jiménez, Ph.D., University of Castilla-La Mancha, Spain

Manuel Vargas-Vargas, Ph.D., University of Castilla-La Mancha, Spain

\begin{abstract}
The university has to train students in skills which according to the demanding requirements of the job market and social environment are the basis of their competitiveness: specific skills or generic skills cutting across the different degrees.

The convergence framework defined by the European Higher Education Area requires the incorporation of educational and psychology progress in skill development, because the teacher becomes a teaching facilitator instead of a transmitter of knowledge, where the students learn to learn and the lecturer teach how to learn; for this the teacher guides students' self-learning, using appropriate resources, working methods and monitoring. This paper examines the skills required of students on social science courses and shows the experience of how to develop, promote and evaluate these skills.
\end{abstract}

Keywords: European Convergence; Innovation; Skills

\section{INTRODUCTION}

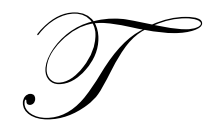

he framework of the European Higher Education Area (EHEA) defined in the Bologna declaration of 1999 establishes the need formulate new education structures, adapting education programmes and teaching methods to new challenges focused on the acquisition and development by students of the skills that will be demanded of them in the job market.

In the design of degree studies, the skills students of each degree should acquire are established, distinguishing between generic skills (shared by all degrees) and specific ones (related with a particular area of knowledge).

The teaching guide for each subject needs to be prepared choosing the skills for the degree that are to be worked on in each course to enable them to be achieved. Obviously this selection will be conditioned not only by the capability of a subject to contribute towards attainment of the skills, but they must also be liable to assessment, for which purpose suitable teaching/learning methods need to be formulated.

For development of these skills, an active teaching method and appropriate methods need to be designed to facilitate the learning of these skills, which implies a challenge of pedagogical innovation, changing from a teaching-focused model to a learning-focused one (De Miguel et al, 2006), where students play a more active rove and where it is not the same to show what should be done as to put what has been learned into practice (Gilbert, 1981).

In this role, the teacher adopts the role of tutor-facilitator (defined by Eisenbeis, 1994), i.e., initially "facilitator", explaining the basic contents of the courses and thereafter proposing a series of methods and allowing freedom for the students to develop their ideas, so achieving maximum levels of creativity and learning. 
De Miguel et al (2006) consider that quality learning is achieved by brining students face-to-face with real situations in which they can apply their skills and make decisions, learning independently, reflexively and critically. In this sense, Biggs (2005) establishes that for students to learn well, four conditions need to be met:

- $\quad$ A well structured basis of knowledge

- $\quad$ An adequate motivational context

- $\quad$ Activity by the student

- $\quad$ Interaction with classmates

The real challenge lies in how to get students to learn independently on their own. In this context, De Miguel et al (2006) establish that students are more motivated when given successive goals than when a long-term objective is proposed. In addition, the greater involvement in the process reduces failure and the drop-out rate (López, 2011).

The aim seems clear: to develop skills, but how can the degree of skill acquisition be measured, and should we assess teaching contents or concentrate on assessing skills?

The question is not whether to assess teaching and skills separately, but to understand that skills are not just attitudes and abilities like team work, team leadership, communication and self-motivation, among others, but also involve knowledge of the subject (Race, 2003); therefore skills consist of the interaction between academic training and workplace performance.

In this context, the objective of this study is to analyse how the teaching guides of different courses of the degree in business management have adapted to this new framework, and specifically to find out whether the processed assessment procedures allow the skills defined to be evaluated.

\section{CRITERIA FOR METHODOLOGICAL RENOVATION}

The present teaching process defined by the EHEA framework shifts attention from the teacher's teaching to the student's learning (Tagg, 2003); the planning and execution of this process must be carried out from its three constituent elements:

\section{- $\quad$ Form \\ - Method \\ - $\quad$ Assessment systems} skills defined.

These three elements being oriented towards the acquisition and development of the generic and specific

\subsection{Form}

The traditional distinction is between two forms of teaching, to each of which a certain proportion of a subject's total number of credits is assigned:

\section{- $\quad$ Theoretical classes \\ - $\quad$ Practical classes}

The two forms are considered insufficient for the new teaching framework, making it necessary to adopt a broader range of organizational forms, beginning with the prior distinction between class time and non-class time. 
The organizational forms in class time include:

- $\quad$ Theoretical classes: explanation of basic contents

- $\quad$ Seminars and workshops: interaction to establish in-depth knowledge

- $\quad$ Practical classes: the application of knowledge to specific situations

- Work practise: in a professional context

- Tutorials

And the forms in non-class or autonomous time include:

- $\quad$ Group work and study

- Individual, autonomous work and study on the course.

Chose of the teaching form will also depend on the objective being followed and on the number of students

De Miguel et al (2006) carried out an empirical study which shows how group work and seminars help the development of skills more than theoretical classes.

\subsection{Method}

Method consists of the definition of a process or plan of action to achieve objectives, and should be characterized by putting forward a large number of learning activities (Zabala, 1989).

The most suitable teaching methods for university students include the following:

- $\quad$ Expository method: lectures

- $\quad$ Case study

- $\quad$ Exercises and problem solving

- $\quad$ Problem-based learning (PBL)

- $\quad$ Project-oriented learning

- $\quad$ Cooperative learning

- $\quad$ Learning contract: independent study supervised by the teacher

Different methods may be followed within the same form of teaching to achieve its aims, the choice depending on the skill to be developed.

An empirical study carried out by De Miguel et al (2006) established that project-oriented learning or case studies allow greater development of skills (for all their components) than that achieved with lectures.

\subsection{Assessment systems}

The design of an assessment system adapted to the skills defined for the subject is the key element to achieve the teaching / learning process.

The traditional fundamental element of assessment has been the examination (Morales, 2000), but students know the details and criteria too late, when it has already been done. In this sense, Biggs (2005) and Ramsden (1992) state that students should know the criteria necessary to get good results beforehand.

Biggs (2005) defines the main differences between the traditional assessment system and skill focused assessment (Table 1). 
Table 1: Differences between traditional assessment and skill-focused assessment

\begin{tabular}{|l|l|}
\hline \multicolumn{1}{|c|}{ Traditional assessment } & \multicolumn{1}{c|}{ Skill-focused assessment } \\
\hline Assessment limited to knowledge & Authentic/holistic assessment (of knowledge, skills and attitudes) \\
\hline Assessment related to the norm (comparison with the group) & Assessment related with previously established criteria \\
\hline The teacher is the single owner of the assessment & Students as co-owners of the assessment \\
\hline Final and summative assessment & Continuous, formative assessment \\
\hline Assessment by a single procedure and strategy & Mixture assessment strategies and procedures \\
\hline
\end{tabular}

Source: De Miguel et al (2006)

One assessment system which is becoming especially important is the involvement of the student in the assessment process, because of the possibilities it provides to develop different general and specific skills, as well as greater levels of learning (Boud, 1995; Boud and Falchikov, 2007; Brown and Glasner, 2003; Dochy, Segers and Sluijsmans, 1999; Dochy, Segers and Dierick, 2002; Falchikov, 2005; Knight, 2005), especially with regard to shared assessment and self-assessment systems.

The real challenge of the teaching/learning process established in the EHEA is assessment of skills, which cannot be done with a single instrument as has happened until now with the final examination; instead, the most suitable instruments and procedures to assess the different skills need to be selected (López, 2011).

Figure 1: Most suitable assessment strategies for the different skills

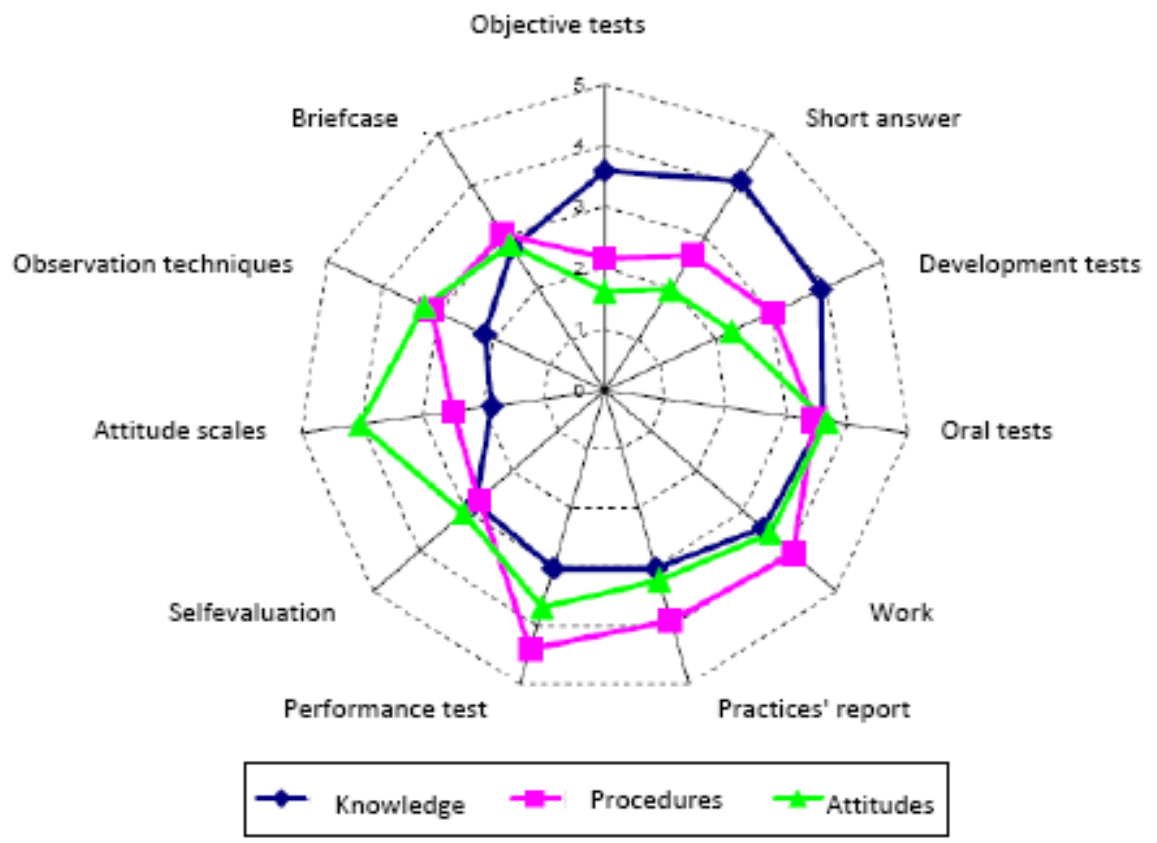

Source: Adapted from De Miguel et al (2006)

\section{TEACHING EXPERIENCE}

We shall now examine how the Grade degree in business studies of the University of Castilla-La Mancha has been adapted to the new framework defined in the EHEA; specifically, we are going to focus on how the teaching/learning and assessment process has been adopted in different subjects corresponding to different areas and established in their corresponding teaching guides. 
In the different courses, the generic (G) and specific (S) skills to be obtained must be established; scenarios must be proposed for each of the teaching forms used, including both class and non-class time forms; and different organizational forms must be used: theory classes, practical classes, group work and independent work.

With regard to teaching methods used, they are lectures, case studies, exercise and problem solving and project-oriented learning - active methods with which it is wanted to encourage students' independent study and to place them in contact with the real problems and situations they will find in their course of their professional career, thereby achieving effective learning by students.

Finally, the assessment system designed, allowing the acquisition level of the skills assigned and the specific knowledge of the subjects to be verified, uses these different procedures:

- $\quad$ Practical-theoretical long-answer tests

- $\quad$ Group work

- $\quad$ Oral tests: group work presentation

- $\quad$ Assessment of the oral presentation of group work by the other students

- $\quad$ Observation techniques using the recording of other practical activities carried out in class

One of the most important innovations in this context consists of the incorporation of information and communications technology (ICT) to traditional teaching, through which we must be able to redirect teaching and adapt to the new teaching scenarios (Mondéjar, Mondéjar and Vargas, 2006). These new tools, put into practice in practically all classroom universities, have helped to meet the needs of students who combine study and work (Mondéjar, Mondéjar and Vargas, 2007).

Two possibilities therefore exist for students, classroom and semi-distant learning, which two alternative ways of assessment, the purpose of which is to detect the development of these skills and the acquisition of new abilities and skills. For this purpose, the launching of these programmes with alternative systems according to the type of student should be capable of treating classroom and semi-distant students equally.

The learning process presented is characterized by students playing an important role in their own learning, adopting an active role in the model, method and assessment system, so allowing them to develop the skills to the level required for the degree, as well as acquire the specific knowledge of its subjects.

\section{CONCLUSIONS}

Social science teaching methods designed have enriched the learning process, facilitated skill acquisition and development, and also managed to increase students' motivation, participation and interaction, but the main disadvantage of this is the work load placed on both student and teacher, which requires coordination among the teaching staff in any particular course to organize activities and even carry out joint activities which reduce the number of student activities and their concentration at particular times.

It should be remembered that skill assessment is not only concerned with end results, but involves the whole process of learning in which the skills are acquired and developed.

In this context, the assessment system proposed has allowed continuous assessment of students during the academic year, in which sufficient information has been collected by the various evaluation procedures to verify the acquisition of knowledge and the development and knowledge of skills.

While skill assessment may not be new, the differential application in the same, mostly classroom work group, with the assistance of e-learning, is interesting. This new kind of teaching tries to combine new technologies with traditional teaching. It also facilitates the incorporation of students of any age, and class attendance ceases to be one of the essential requirements for students, in a way that does not require competition with or replacement of classroom teaching: the two can be perfectly complementary. 
It should be borne in mind that there are various assessment strategies to evaluate the most suitable contents for different skills, for which reason the teacher plays an important role in defining the strategies which are most suitable for his subject and how the classroom attendance problem should be solved within the framework of the new European Higher Education Area.

The new Grade degree in Business Studies will be fully in place by the end of the academic year 20122013, and we will have the first overall results of these initiatives of the University of Castilla-La Mancha. Nevertheless, experience of this assessment system in the years 2009/2010 and 2010/2011 has been satisfactory, with more satisfactory results than those obtained with traditional teaching and assessment systems.

\section{AUTHOR INFORMATION}

Juan-Antonio Mondéjar-Jiménez, $\mathrm{PhD}$ and Degree in Business Administration by University of Castilla-La Mancha. Degree in Advanced Studies in Marketing at the same university. Associate Professor in Marketing at Business Administration Department. Faculty of Social Sciences of Cuenca. University of Castilla-La Mancha (Spain). E-mail: JuanAntonio.Mondejar@uclm.es.

Research Interest: Consumer behavior, price perception, e-learning and tourism marketing.

María Cordente-Rodríguez, Degree in Business Administration by University of Castilla-La Mancha. Scholar Research in Marketing at Business Administration Department. Faculty of Social Sciences of Cuenca. University of Castilla-La Mancha (Spain). E-mail: Maria.Cordente@uclm.es.

Research Interest: Tourism marketing, consumer behavior and e-learning.

Carlota Lorenzo-Romero, Degree in Business Administration and $\mathrm{PhD}$ on E-Marketing from University of Castilla-La Mancha (Spain). Currently Assistant Professor in Marketing at Business Administration Department. Faculty of Economics and Business Administration of Albacete, University of Castilla-La Mancha (Spain). E-mail: Carlota.Lorenzo@uclm.es

Research Interest: Electronic commerce, Web 2.0, Social Networking Sites, store atmosphere, e-merchandising, online consumer behaviour, marketing research, experimental designs, and quantitative analysis.

José Mondéjar-Jiménez, European $\mathrm{PhD}$ in Economics and Degree in Business Administration by University of Castilla-La Mancha. Degree in Advanced Studies in Statistics at the same university. Associate Professor in Statistics at Statistics Department. Faculty of Social Sciences of Cuenca. University of Castilla-La Mancha (Spain). E-mail: Jose.Mondejar@uclm.es.

Research Interest: Regional analysis, educational, tourism and environment.

Manuel Vargas-Vargas, PhD in Economics by University of Castilla-La Mancha and Degree in Mathematics by University of Granada. Associate Professor in Statistics at Statistics Department. Faculty of Economics and Business Administration of Albacete, University of Castilla-La Mancha (Spain). E-mail: Manuel.Vargas@uclm.es.

Research Interest: State-space models, educational, tourism and environment.

\section{REFERENCES}

1. $\quad$ Biggs J. (2005): Calidad del aprendizaje universitario, Narcea, Madrid.

2. Boud, D. (1995): Enhancing Learning Through Self-Assessment, Routledge, London.

3. Boud, D. and Falchikov, N. (2007): Rethinking Assessment in Higher Education. Learning for the long term, Routledge, Oxon.

4. Brown, S. and Glasner, A. (2003): Evaluar en la universidad. Problemas y nuevos enfoques, Narcea, Madrid. 
5. De Miguel, M. (Dir.); Alfaro, I.J.; Apodaca, P.; Arias, J.M.; García, E.; Lobato, C. and Pérez, A. (2006): Modalidades de enseñanza centradas en el desarrollo de competencias. Orientaciones para promover el cambio metodológico en el Espacio Europeo de Educación Superior, Proyecto EA2005-0118. Programa de estudios y análisis. Dirección General de Universidades. Ministerio de Educación, Cultura y Deporte.

6. Dochy, F.; Segers, M. and Sluijsmans, D. (1999): "The Use of Self-, Peer and Co-assessment in Higher Education: a review", Studies in Higher Education, 24 (3), pp. 331-350.

7. Dochy, F.; Segers, M. and Dierick, S. (2002): "Nuevas vías de aprendizaje y enseñanza y sus consecuencias: una nueva era de Evaluación", Boletín de la RED-U, Vol. 2(2), pp. 13-30.

8. Eisenbeis, H. (1994): "Using the facilitator role in case teaching: a personal perspective", Case Research Journal, Vol. 14 n², pp. 121-133.

9. Falchikov, N. (2005): Improving Assessment Through Student Involvement. Practical solutions for aiding learning in higher and further education, Routledg, Oxon.

10. Gilbert, J. (1991): Guía pedagógica para el personal de la salud, ICE de la Universidad/OMS, Valladolid.

11. Mondéjar, J.; Mondéjar, J.A. and Vargas, M. (2006): "Implantación de la metodología e-learning en la docencia universitaria: una experiencia a través del proyecto Campus Virtual”, RELATEC, Revista Latinoamericana de Tecnología Educativa, 5 (1), pp. 59-71.

12. Mondéjar, J. A.; Mondéjar, J. and Vargas, M. (2007): "Docencia virtual en universidades presenciales: experiencia en la Universidad de Castilla-La Mancha”, RIED: Revista Iberoamericana de Educación a Distancia, 10 (2), pp. 207-228.

13. Morales, P. (2000): Evaluación y aprendizaje de calidad. Guatemala: Universidad Rafael Landívar.

14. Knight, P. (2005): El profesorado de Educación Superior, Narcea, Madrid.

15. López, V.M. (2011): "El papel de la evaluación formativa en la evaluación por competencias: aportaciones de la red de evaluación formativa y compartida en docencia universitaria", Revista de Docencia Universitaria, Vol. 9(1), pp. 159-173.

16. Race, P. (2003): “Por qué evaluar de un modo innovador?”, in Brown, S. and Glasner, A. (Eds.), Evaluar en la universidad. Problemas y nuevos enfoques, Narcea, Madrid.

17. Ramsden, P. (1992): Learning to teach in higher education, Routledge, London.

18. Tagg, J. (2003): The learning paradigm college, Anker Publishing Company, Bolton, MA.

19. Zabala, A. (1989): "El enfoque globalizador", Cuadernos de Pedagogía, 168, pp. 17-22. 
NOTES 